論

\title{
赤外吸収特性に基づいた散布農薬の付着濃度推定法
}

\author{
正会員＼cjkstart德竹＼cjkstart翔太（株式会社西澤電機計器製作所） \\ 正会員 石澤 広明（信州大学）非会員 堀口＼cjkstart拓郎（信州大学） \\ 非会員 吉成 寛樹 (信州大学) \\ 正会員 山田 久也（ヤンマーグリーンシステム株式会社）

\section{Measuring Pesticide Residue Based on Infrared Absorption Features} \\ Member Shota Tokutake (Nishizawa Electric Meters Manufacturing Co., Ltd.), Member Hiroaki Ishizawa (Shinshu University), \\ Non Member Takuro Horiguchi (Shinshu University), Non Member Hiroki Yoshinari (Shinshu University) \\ and Member Hisaya Yamada (Yanmar Green System Co., Ltd.)
}

\begin{abstract}
This paper describes an original method for measuring pesticide residue. Recently, the demand for measurement of pesticide residue has increased because the concern of safety of the consumer's food has risen. Furthermore, the dispersion of the pesticide (drift) has become an urgent problem. However, existing methods involve destructive inspection, and a lot of time and proficiency is necessary for the analysis.

In this study, to solve those problems, we propose the application of infrared spectroscopy, which is a nondestructive measurement technique. This is a measuring method that assumes the adhesion density of agricultural chemicals using the IR spectrum and SIMCA.
\end{abstract}

KEYWORDS : pesticide residue, drift, infrared spectroscopy, SIMCA, nondestructive

\section{1. 緒言}

近年，表示偽装など食品に関する事件が相次ぎ，一般消費者は食 品の安全性に対して高い関心を示すようになった. 特に懸念される 問題として農作物における残留農薬があり, この原因の 1 つに農薬 のドリフトが挙げられる。これは風などの影響で他の戋場や居住 地，河川などに農薬が飛散することを指す，そして農薬に関するこ れら諸問題に対して農薬取締法・食品衛生法・水道法などで法律が 定められており, また, 農作物の収量・品質の低下の要因とも成り 得ることから，生産者の固場管理に対寸る意識が高まってきてい る.そのために従来, 感水紙を用いたドリフト試験が実施されてい るが, これは農薬の飛散状況を確認することが目的であり, 農薬の 飛散量まで推定することはできない. また, 2006 年にポジティブ リスト制度 1)が導入されたことで基準の定められていない農薬が一 律基準值 $(0.01 \mathrm{ppm})$ 以上残留している農作物の流通が一切禁止と なるため, 残留農薬測定の重要性が増し, その需要が高まってきて いるのが現状である。一般に, 残留する農薬量の単位として ppm: parts per million（百万分率）が用いられ，1 ppm とは食品 $1 \mathrm{~kg}$ 中に $1 \mathrm{mg}$ の農薬が残留していることを示す.

現在, ポジティブリスト制度が定める残留農薬検査の公定法とし て, 化学的手法であるガスクロマトグラフィー, 液体クロマトグラ フィーなどが採用され実施されている. しかしながら，これら分析 手法は試料の残留農薬を測定するまでに様々な薬品を必要とし, 抽 出・精製といった繁雑な工程を要するものである ${ }^{2)}$. 加えて, これ らは破壊計測であり，分析に多くの時間を費やすことや，高コスト といった問題も抱えている.
上述した問題点を改善するため, 本研究では赤外分光放射計測 による迅速かつ簡便に農薬付着濃度が推定可能なドリフト試験 方法を提案している ${ }^{3) \cdot 7)}$. 本手法は, 農薬を散布した捕集材につ いて赤外吸収スペクトルを測定し, これに多変量解析の一種であ る Soft Independent Modeling of Class Analogy(以下 SIMCA) を適用することで農薬の付着濃度ごと分類を行なうものである。 先行研究において, 感水紙を捕集材として調製した農薬散布試料 について測定した結果, 農薬の付着濃度ごとにスペクトル分類す ることは困難であった ${ }^{6)}$.これは, 感水紙の赤外吸収特性, そし て農薬を散布することで表面形状が変化することがその原因と して挙げられた．本稿では撥水性の高いポリエチレンを採用し, 屋内模擬試験をへて実際に無人ヘリコプター散布を実施, 調製し た農薬散布試料について本手法が適用可能か検討を行なった。

\section{2. 原理および測定装置}

\section{1 赤外分光法}

物質に赤外光が照射されると, 分子で吸収が起こり高エネルギ 一状態へと遷移する. 赤外吸収は分子振動のエネルギー準位間の 遷移に基づくものであり, 振動数は構成原子の質量や原子間に働 く力の大きさによって決定される. 寸なわち, 吸収波長帯は分子 固有となるため, 赤外吸収スペクトルを取得することで物質の定 性分析が可能となる 7)。 また, Lambert-Beer 則 9)を適用するこ とで，試料濃度と吸光度に比例関係があるとし定量を試みる. な お, 捕集材自体も赤外吸収特性を有しているため, 農薬有効成分 の情報のみを抽出することで付着濃度ごとの分類が可能となる. 


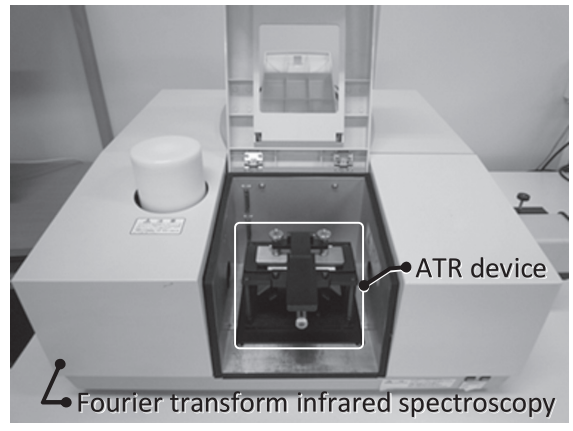

図 1 フーリエ変換赤外分光光度計および ATR 装置

Fig. 1 Measurement device.
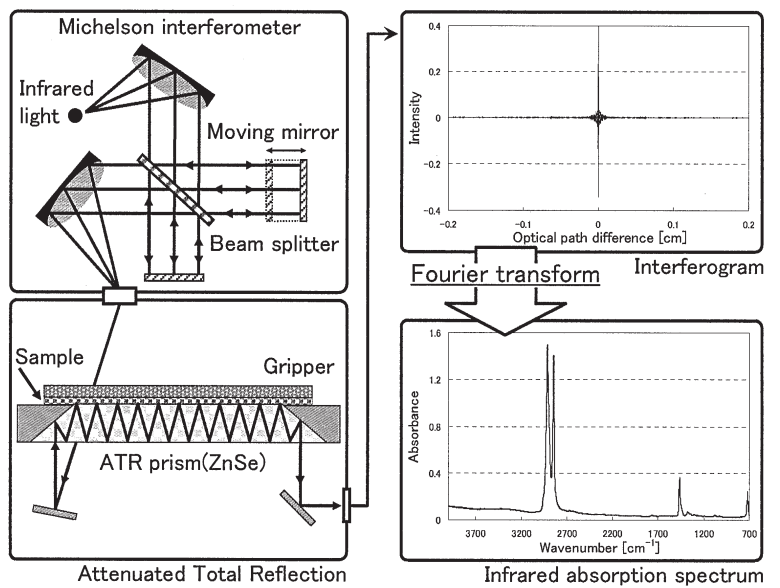

図 2 赤外吸収スペクトル測定の概略図

Fig. 2 Schematic diagram of spectrum measurement.

本研究では，赤外吸収スペクトルの測定手法として全反射減衰 法（以下 ATR 法: Attenuated Total Reflection Method）を採用し ている，そして，図 1 に示すようなフーリエ変換赤外分光光度計 (IRPrestige-21：島津製作所) およびATR 装置 (Contact Sampler: Spectra Tech. Inc）から構成される装置により赤外吸収スペクトル を取得した. 光源から発せられた赤外光は, マイケルソン干涉計を へて干渉光となり, ZnSe 単結晶から成る ATR プリズムへと入射, プリズム内で全反射を繰り返して進む（図 2)。その際，プリズム に密着した試料表面にエバネッセント波が侵入し, 赤外吸収が生じ て減衰光となる。これはインターフェログラムと呼ばれる干渉縞と して検出され，フーリエ変換することで農薬の情報を含む赤外吸収 スペクトルが得られる.

\section{2 Soft Independent Modeling of Class Analogy}

スペクトル解析には, ケモメトリックスのパターン分類手法であ る Soft Independent Modeling of Class Analogy10) (Pirouette ver.4：Infometrix）を採用した. SIMCA は，目的変数を使用しない 主成分分析とは異なり，質的あるいは量的な変数で表された目的変 数に沿うように，説明変数中に潜在的に含まれる因子を抽出して分 類する手法である.ある共通性をもった各試料群（クラス）につい て主成分分析を行ない, 得られた主成分得点の分布の広がりに基づ
きSIMCA box と呼ばれる判別空間を構築する. SIMCA box は主 成分ベクトルで張られる判別空間において, 各クラスの広がりを 残差の変動を用いて定義される，そして，試料データ群に対する 残差の分散を比較し, $\mathrm{F}$ 検定によって判別を行なう. 本研究では, 農薬の濃度区ごとにクラスを構築, 付着濃度ごとのスペクトル分 類を試みた。 なお, 構築した SIMCA box との位置関係により, 未知試料は以下のように分類される. (1) 一意にいずれかのクラ スに帰属させる, (2) 2 つ以上のクラスに帰属させる, (3) 構築し たどのクラスにも属さない異常試料, これら 3 パターンである.

また，クラスを構成している各スペクトルを他クラスに適用 し，残差を算出することで，クラス間を区別する因子を特定でき る識別力 (Discrimination Power) が得られる.その識別力の算 出式を(1)式として示す.

$$
D P_{j}=\frac{1}{Q-1} \frac{\sum_{q}^{Q} \sum_{r}^{Q}\left(q e_{i r}\right)^{T}\left(q e_{j r}\right)}{\sum_{r}^{Q}\left(r e_{j r}\right)^{T}\left(r e_{j r}\right)} \quad \ldots \text { (1) }
$$

ここで, $Q$ は全クラス数を示し, 残差ベクトル $q e_{j r}$ は, クラス $r$ のトレーニングセットのサンプルをクラス $q$ のモデルに適合さ せた後の残差行列の $j$ 番目の列を意味する. 本研究では, 構築し た分類モデルの妥当性について検証するため, その指標として識 別力を利用した.

\section{3. 実験方法}

\section{1 散布農薬および捕集材}

無人ヘリコプターによる農薬散布は, 国内において年々増加し てきているのが現状であり，水稲防除がその大部分を占めてい る. そのような背景から，本実験では水稲に対して常用されてい る有効成分, フサライドを含有する農薬を分析対象とした。 フサ ライドを有効成分とするラブサイド®フロアブルの詳細および, その赤外吸収スペクトルをそれぞれ表 1, 図 3 として示す.

ラブサイド®フロアブルは，いもち病防除に利用されている殺 菌剤であり, 界面活性剤としてエチレングリコールを含有してい

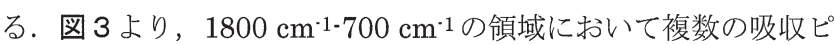
一クが確認でき，特に強い吸収は水によるものである. $1770 \mathrm{~cm}^{1}$ のピークは不飽和 $\gamma$-ラクトン ( 5 員環) の $\mathrm{C}=\mathrm{O}$ 伸縮に帰属する と考えられ, 有効成分による吸収である.また, 他にも C-Cl (1400 $\left.\mathrm{cm}^{-1}, 1330 \mathrm{~cm}^{-1}\right)$ やラクトンの $\mathrm{C}-\mathrm{O}$ 伸縮 $\left(1180 \mathrm{~cm}^{-1}\right)$, クロロ ベンゼン $\left(1080 \mathrm{~cm}^{-1}, 1030 \mathrm{~cm} \cdot 1\right)$ による特徵的な吸収が確認で きる.

\section{表 1 ラブサイドフロアブル詳細}

Table 1 Information of Rabcide.

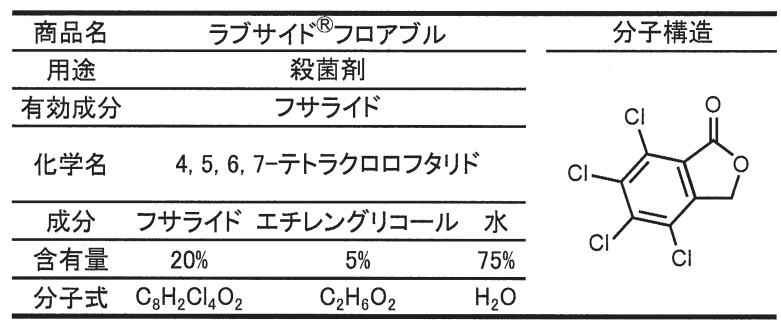




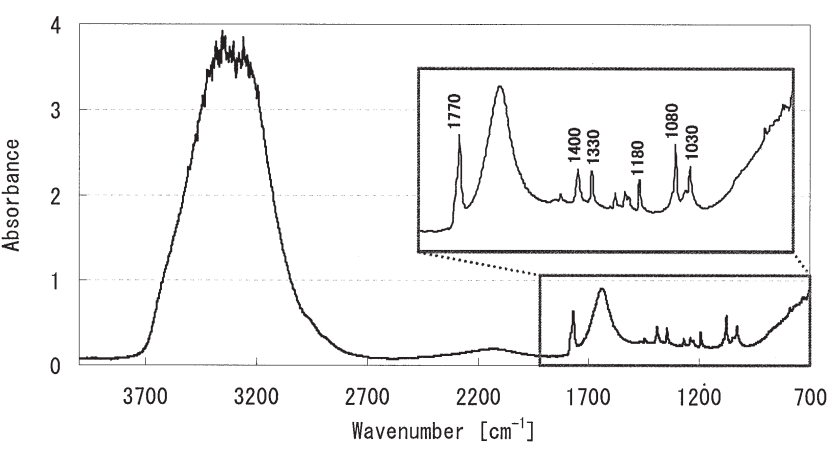

図 3 ラブサイド®フロアブルの赤外吸収スペクトル

Fig. 3 IR spectrum of Rabcide.

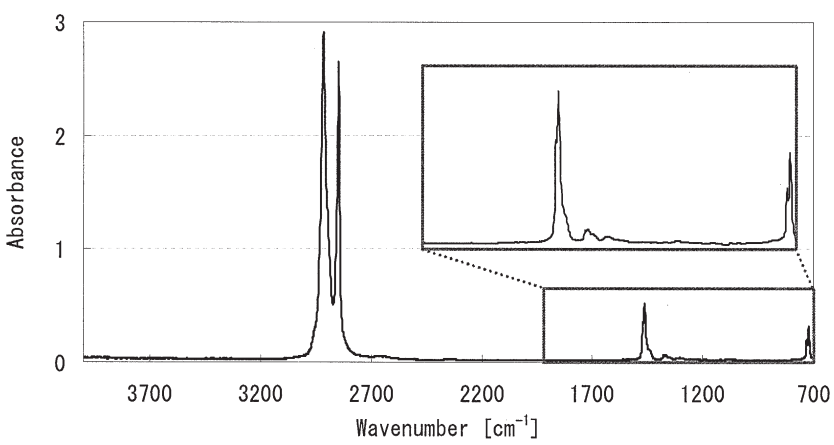

図 4 ポリエチレンシートの赤外吸収スペクトル

Fig. 4 IR spectrum of Polyethylene sheet.

スペクトルの測定手法として ATR 法を採用しているが，これは 試料表面の情報を取得するものであり,プリズムと試料との密着が 不完全であるとノイズが生じる恐れがある。したがって, 農薬散布 によって濡れても表面形状が変化しない素材が捕集材として有効 であり, 本研究では軟質ポリエチレンを採用した. 図4に示寸とお り, ポリエチレンは $1800 \mathrm{~cm}^{11-700 ~} \mathrm{~cm}^{-1}$ の領域において吸収が少な く, 農薬有効成分の吸収情報を阻害しないことも選定理由として挙 げられる.なお，現場での扱いや寸さを向上させるため，厚さ 0.3 $\mathrm{mm}$ の軟質ポリエチレンシート $(15 \mathrm{~mm} \times 100 \mathrm{~mm})$ を樹脂板に貼 り付けたものを捕集材として使用した.

\section{2 屋内散布試験による試料調製}

無人ヘリコプター散布および空中散布では，希釈倍率 8 倍，30 倍とした農薬が散布されている.よって, これらの濃度区およびそ の 10 倍希釈である 300 倍を含めた 3 種の溶液を調製し, 長野県小 諸市にある社団法人 農林水産航空協会 農林航空技術センター内 の実験施設にて農薬散布試験を実施した. 屋内試験では, 遠心力に より放射するロータリーアトマイザーを搭載した走行式散布装置 を使用することで, 実際の無人ヘリコプター散布を再現し, 地上 $4.7 \mathrm{~m}$ の高さから散布を実施した。

捕集材の配置図を図 5 に示す. 両端において, 1 籄所に 2 枚の捕 集材を配置することで, 各濃度区につき 25 試料とし計 75 試料を 調製した。 なお, 散布した農薬の付着量を確認するため, 散布装置
の真下および両端に配置した試料それぞれの代表として C および $\mathrm{H}$ の場所に 1 枚多く捕集材を配置しており，それらを委託分析用 とした. フサライドの付着量分析結果を表 2 に示寸. 表 2 に示した 付着量は, 財団法人 日本食品分析センターに委託し公定法 11)に従 って算出した值である. 中央部と端で付着量に差が見られ，これは 散布装置の放射原理に起因すると考えられる. 同濃度区で付着量に 大きな差が見られなかったため, 濃度ごと分類を行なった。

\section{3 屋外散布試験による試料調製}

無人ヘリコプター (A4H-3: YANMAR) を使用することで, 前節 と同条件のもと屋外散布試験を実施した. 捕集材の配置位置も図 5 と同様であるが, 屋内とは異なり風などの影響で一様に散布するの は困難だと考えられるため, 付着量の分析用として 3 試料(場所： C, H，M）を配置することとした．屋外散布試料におけるフサライド の付着量分析結果について表 3 に示寸. やはり, 屋内と異なる傾向 が見られたが, 比較的一様に散布されていることが確認された.

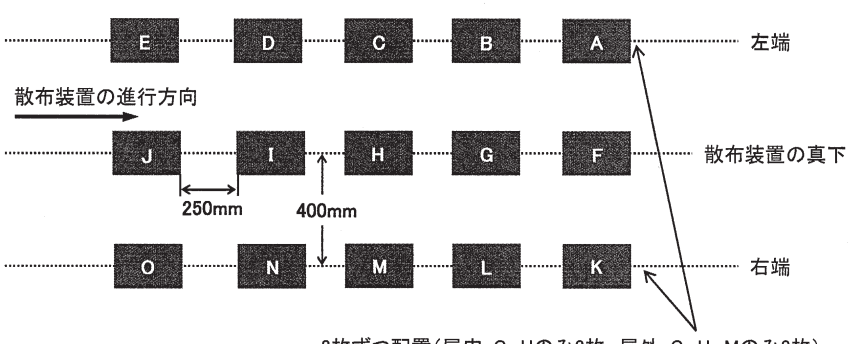

2枚ずつ配置(屋内: C, Hのみ3枚, 屋外: C, H, Mのみ3枚)

\section{図 5 捕集材の配置図}

Fig. 5 Layout plan of sample.

\section{表 2 屋内試験におけるフサライド付着量分析結果}

Table 2 Assay result of interior sample.

\begin{tabular}{cc}
\hline Sample name & Fthalide $[\mu \mathrm{g}]$ \\
\hline $8-\mathrm{C}$ & 44 \\
\hline $8-\mathrm{H}$ & 28 \\
\hline $30-\mathrm{C}$ & 8.6 \\
\hline $30-\mathrm{H}$ & 5.6 \\
\hline $300-\mathrm{C}$ & 0.6 \\
\hline $300-\mathrm{H}$ & 0.4 \\
\hline * 濃度-配置場所-試料番号(以下の表記これに倣う)
\end{tabular}

\section{表 3 屋外試験におけるフサライド付着量分析結果}

Table 3 Assay result of outside sample.

\begin{tabular}{cc}
\hline Sample name & Fthalide $[\mu \mathrm{g}]$ \\
\hline $8-\mathrm{C}$ & 24 \\
\hline $8-\mathrm{H}$ & 28 \\
\hline $8-\mathrm{M}$ & 30 \\
\hline $30-\mathrm{C}$ & 11 \\
\hline $30-\mathrm{H}$ & 14 \\
\hline $30-M$ & 15 \\
\hline $300-\mathrm{C}$ & 0.8 \\
\hline $300-\mathrm{H}$ & 1.1 \\
\hline $300-M$ & 1.4 \\
\hline
\end{tabular}




\subsection{SIMCA による付着濃度分類モデルの構築}

農薬散布後, 乾燥した各試料について ATR 法により赤外吸収ス

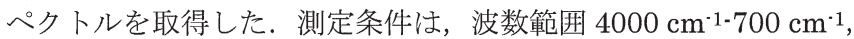
分解能 $4 \mathrm{~cm}^{-1}$, 積算回数 20 回, DLATGS を検出器とした. なお, 農薬付着有無の判別について検討寸るため, 手技によるスプレー散 布にて水散布試料 30 試料を調製, 同様にスペクトル測定を実施し た. 他試料と配置・散布方法が異なるが, 表面状態の変化について 確認することが主目的となるため, 影響はないものと考えている. そして図 6 に示寸ように農薬無散布クラス (Class 0), 希釈倍率 8 倍クラス (Class 8), 30 倍クラス (Class 30), 300 倍クラス (Class 300）の 4 つのクラスを作成し, SIMCA により農薬の付着濃度ご とのスペクトル分類を行なった. 各クラスは無作為に選定した 20 試料のスペクトルデータにより作成, 残りの 25 試料をモデル検証 用とした. また, モデル構築用試料の組み合わせを変化させること により検証を 5 回行ない, モデルの安定性についても確認した.

\begin{tabular}{|c|c|c|c|}
\hline $\begin{array}{l}\text { Class } 0 \\
\text { No spray } \\
\text { (20 Samples) }\end{array}$ & $\begin{array}{c}\text { Class } 8 \\
\text { Diluted } 8 \text { fold } \\
(20 \text { Samples) }\end{array}$ & $\begin{array}{l}\text { Class } 30 \\
\text { Diluted } 30 \text { fold } \\
(20 \text { Samples })\end{array}$ & $\begin{array}{c}\text { Class } 300 \\
\text { Diluted } 300 \text { fold } \\
\text { (20 Samples) }\end{array}$ \\
\hline
\end{tabular}

Validation 25 Samples

(Class 0: 10 Samples, Class 8: 5 Samples, Class 30: 5 Samples, Class 300: 5 Samples)

\section{図 6 SIMCA による農薬付着濃度分類モデル}

Fig. 6 SIMCA model.

\section{4. 結果および考察}

\section{1 赤外吸収スペクトル}

屋内散布試料および屋外散布試料それぞれについて取得した赤 外吸収スペクトルを図 7, 図8に示す. 図示したのは有効成分によ る吸収が多数確認された $1800 \mathrm{~cm}^{-1-700 ~} \mathrm{~cm}^{-1}$ の領域を拡大してお り, 濃度ごとに平均して比較したものである. なお, 各波数 $\lambda_{\mathrm{j}}$ に おける強度值に係数 $\lambda_{j} / \lambda_{\text {ref }}$ を掛けることにより ATR 補正 (IRsolution：島津製作所)を施している $\left(\lambda_{\text {ref }}=2000 \mathrm{~cm}^{-1}\right)$. 屋内およ び屋外散布試料の両者において, 有効成分であるフサライド特有の 吸収が検出可能であった. そして, 主に $1770 \mathrm{~cm}^{-1}, 1180 \mathrm{~cm}^{-1}, 1080$ $\mathrm{cm}^{-1}, 1030 \mathrm{~cm}^{-1}$ 付近において, 有効成分の濃度变化に伴う吸光度 の変動も顕著に確認された. ポリエチレン自体の強い吸収も見られ るがピークは重複していないため, この領域(1800 cm-1-700 cm-1) について解析を行なうことで農薬の付着濃度分類を試みた。

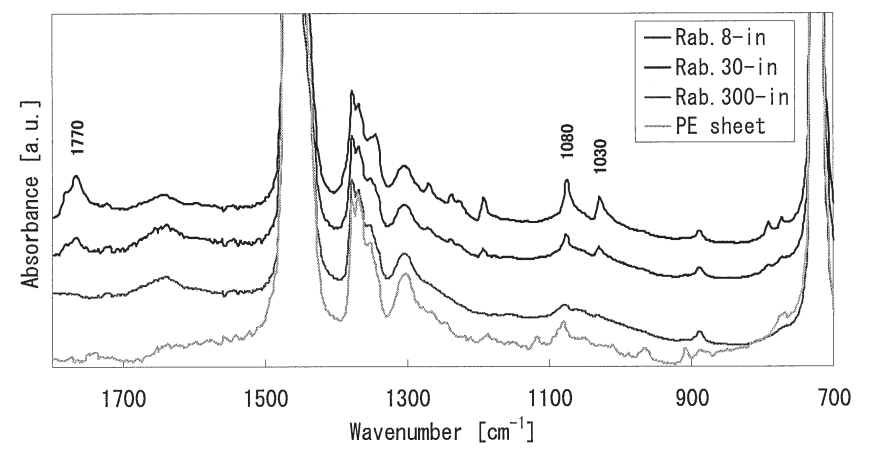

図 7 屋内散布試料の赤外吸収スペクトル

Fig. 7 IR spectra of interior sample.

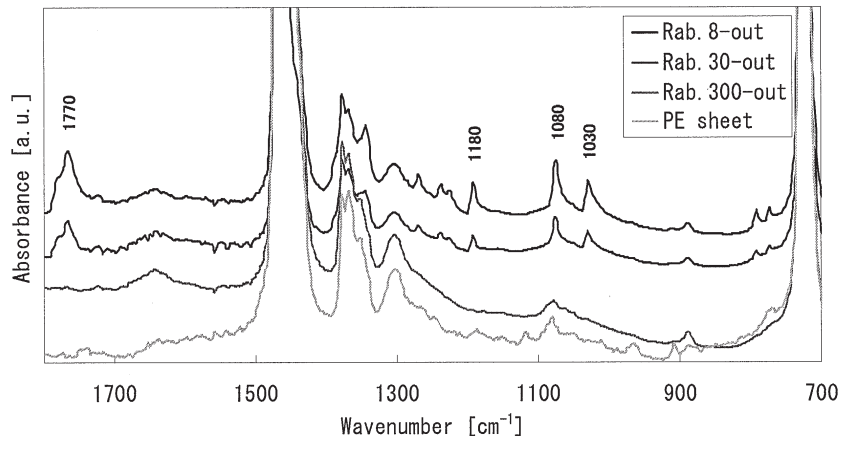

図 8 屋外散布試料の赤外吸収スペクトル

Fig. 8 IR spectra of outside sample.

\section{2 屋内散布試料の付着濃度スペクトル分類}

解析波数範囲を $1800 \mathrm{~cm}^{-1-700 ~} \mathrm{~cm}^{-1}$ とし, ATR 補正および Savitzky- Golay 法による一次微分処理(IRsolution：島津製作所） を施したスペクトルについて分類を行なった. 表 4 に分類結果を示 す. 5 パターンのモデルのどのクラスにおいても, 80 \%以上の分類 正答率が得られ, モデルの安定性について確認された.

ここで, 他と比較し誤判別が多かったモデル I の分類結果詳細に ついて表 5 に示寸. 誤判別となった試料（8-E-1）は， 2 番目に適 合度の高いクラスを示す NextBest 1 において正しい分類結果が得 られていることが分かる. したがって, この誤判別が付着量の差異 によるものだと推定しても原理的に矛盾はなく, 本手法を農薬散布 試料に適用するその妥当性を示すことができたと考える.

\section{表 4 屋内散布試料の分類結果}

Table 4 Classification result of interior sample.

\begin{tabular}{lcccccc}
\hline & \multicolumn{7}{c}{ Model No. } \\
\cline { 2 - 7 } & I & I & III & IV & V & Ave. [\%] \\
\hline Class 0 & $10 / 10$ & $10 / 10$ & $10 / 10$ & $10 / 10$ & $10 / 10$ & 100 \\
\hline Class 8 & $4 / 5$ & $5 / 5$ & $5 / 5$ & $5 / 5$ & $4 / 5$ & 92 \\
\hline Class 30 & $5 / 5$ & $5 / 5$ & $4 / 5$ & $5 / 5$ & $5 / 5$ & 96 \\
\hline Class 300 & $4 / 5$ & $4 / 5$ & $5 / 5$ & $4 / 5$ & $4 / 5$ & 84 \\
\hline
\end{tabular}

表 5 屋内散布試料の分類結果詳細（モデル I )

Table 5 Details of classification result (model I).

\begin{tabular}{cccccc}
\hline & Sample name & Best & NextBest 1 & NextBest 2 \\
\hline Class 0 & All samples & 0 & - & - \\
\hline & $8-\mathrm{A}-2$ & 8 & - & - \\
\cline { 2 - 5 } Class 8 8 & $8-\mathrm{E}-1$ & 30 & 8 & - \\
\cline { 2 - 5 } & $8-\mathrm{G}-1$ & 8 & - & - \\
\cline { 2 - 5 } & $8-\mathrm{I}-1$ & 8 & - & - \\
\cline { 2 - 5 } & $8-\mathrm{O}-2$ & 8 & - & - \\
\hline & $30-\mathrm{A}-2$ & 30 & 300 & - \\
\cline { 2 - 5 } & $30-\mathrm{E}-1$ & 30 & 300 & - \\
\cline { 2 - 5 } Class 30 & $30-\mathrm{G}-1$ & 30 & 300 & - \\
\cline { 2 - 5 } & $30-\mathrm{I}-1$ & 30 & - & - \\
\cline { 2 - 5 } & $30-\mathrm{O}-2$ & 30 & - & - \\
\hline \multirow{5}{*}{ Class 300 } & $300-\mathrm{D}-1$ & 300 & 30 & - \\
\cline { 2 - 5 } & $300-\mathrm{E}-1$ & - & - & - \\
\cline { 2 - 5 } & $300-\mathrm{G}-1$ & 300 & 30 & - \\
\cline { 2 - 5 } & $300-\mathrm{I}-1$ & 300 & 30 & - \\
\cline { 2 - 5 } & $300-\mathrm{O}-2$ & 300 & 30 & - \\
\hline
\end{tabular}




\section{3 屋外散布試料の付着濃度スペクトル分類}

解析波数範囲を $1800 \mathrm{~cm}^{-1-700 ~} \mathrm{~cm}^{-1}$ とし，ATR 補正および一次 微分処理を施したスペクトルについて分類を行なった. 分類結果に ついて表 6 に示す. 屋内散布モデルと同様, どのクラスにおいても $90 \%$ 近い分類正答率が得られ, 構築したモデルの安定性について 確認できた。これは，SIMCAにおいて作成したクラスごとに主成 分分析を行なうことで, 適確に農薬の濃度情報を抽出できたためだ と考えられる. 特に, 農薬無散布クラス (Class 0) においてその 分類正答率は $100 \%$ を示していることから, 農薬付着の有無につい ては確実に判別が可能であると言える. 表 7 にモデルVの分類結果 詳細について示す. 正しく分類されなかった試料はいずれも未分類 となっており,これはスペクトル測定時の不備によるスペクトル形 状の差異が要因となっている. したがって, 安定してスペクトルを 取得する方法について再検討する必要があり, 今後の課題となる. 以上の結果より，無人ヘリコプター散布により調製した試料につい ても本手法が適用可能であると考えられ，その有用性を示した.

次に, 図 9 として農薬およびその有効成分の一次微分スペクトル と識別力との比較結果を示す. 微分スペクトルおよび識別力の主な ピーク位置の一致が見られたことから, 分類に大きく影響を与えて いる因子が農薬によるものであると言える。なお, 図示した識別力 は, 図 7, 図8のスペクトル解析結果であり, 屋内散布モデルおよ び屋外散布モデルで概ね一致したことから, 両者ともにその妥当性 が示された．また，界面活性剤など他の成分に影響されず，主に有 効成分の情報によって分類されていることから, フサライドを含む 他の農薬についても本手法が適用できる可能性が示唆された.

\section{表 6 屋外散布試料の分類結果}

Table 6 Classification result of outside sample.

\begin{tabular}{lcccccc}
\hline & \multicolumn{7}{c}{ Model No. } \\
\cline { 2 - 7 } & I & I & II & IV & V & Ave. [\%] \\
\hline Class 0 & $10 / 10$ & $10 / 10$ & $10 / 10$ & $10 / 10$ & $10 / 10$ & 100 \\
\hline Class 8 & $5 / 5$ & $4 / 5$ & $5 / 5$ & $5 / 5$ & $5 / 5$ & 96 \\
\hline Class 30 & $5 / 5$ & $5 / 5$ & $5 / 5$ & $5 / 5$ & $4 / 5$ & 96 \\
\hline Class 300 & $5 / 5$ & $5 / 5$ & $4 / 5$ & $4 / 5$ & $4 / 5$ & 88 \\
\hline & & & & (correct / total)
\end{tabular}

表 7 屋外散布試料の分類結果詳細（モデルV）

Table 7 Details of classification result (model V).

\begin{tabular}{ccc}
\hline & \multicolumn{1}{c}{ Sample name } & Best \\
\hline Class 0 & All samples & 0 \\
\hline & $8-\mathrm{C}-1$ & 8 \\
\cline { 2 - 3 } Class 8 & $8-\mathrm{D}-2$ & 8 \\
\cline { 2 - 3 } & $8-\mathrm{E}-2$ & 8 \\
\cline { 2 - 3 } & $8-\mathrm{K}-1$ & 8 \\
\cline { 2 - 3 } & $8-\mathrm{N}-2$ & 8 \\
\hline \multirow{5}{*}{ Class 30 } & $30-\mathrm{C}-1$ & - \\
\cline { 2 - 3 } & $30-\mathrm{D}-2$ & 30 \\
\cline { 2 - 3 } & $30-\mathrm{E}-2$ & 30 \\
\cline { 2 - 3 } & $30-\mathrm{K}-1$ & 30 \\
\cline { 2 - 3 } & $30-\mathrm{N}-2$ & 30 \\
\hline \multirow{5}{*}{ Class 300 } & $300-\mathrm{C}-1$ & 300 \\
\cline { 2 - 3 } & $300-\mathrm{D}-2$ & - \\
\cline { 2 - 3 } & $300-\mathrm{E}-2$ & 300 \\
\cline { 2 - 3 } & $300-\mathrm{K}-1$ & 300 \\
\cline { 2 - 3 } & $300-\mathrm{N}-2$ & 300 \\
\hline
\end{tabular}

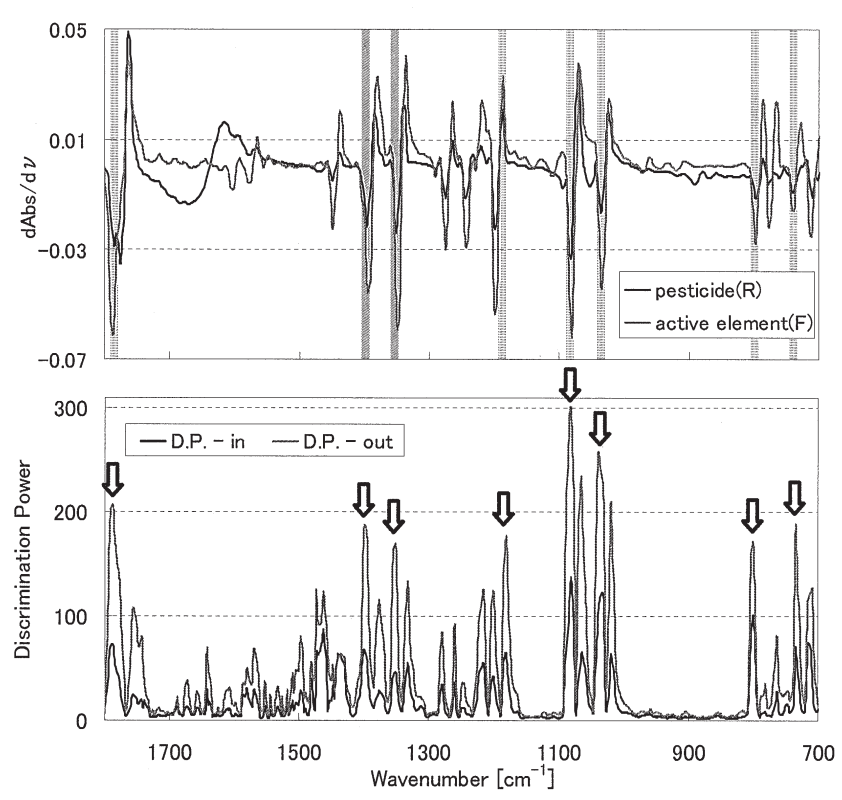

図 9 一次微分スペクトルと識別カとの比較

Fig. 9 Derivative spectrum and Discrimination Power.

\section{4 屋内散布モデルへの屋外散布試料の適用}

前節において, 分類に大きく影響している因子が農薬によるも のであると示した。しかしながら，特に屋外散布において風など の影響で農薬以外のものが捕集材に付着し，その情報も分類に寄 与している可能性が懸念される。したがって，その確認を行なう ため屋内散布モデルへの屋外散布試料の適用を図る.

屋内散布試料のスペクトルにより，図６に示すようなモデルを 再構築し，屋外散布試料のスペクトル分類を試みた。なお，屋内 散布試料のスペクトル全てをモデル構築用としたため, 各クラス 25 試料より構成されている.ただし, 水散布試料は全部で 30 試 料であるため, Class 0 のみ無作為に選定した 20 試料によって構 築, 残りの 10 試料を当てはめ検証用とした. 分類結果を表 8 とし て示す．表中の対角線上の值が分類正答数を示しており，いずれ のクラスにおいても 80 \%以上と高い正答率が得られたことが分か る. しかしながら, Class 300 と比較して農薬の付着量が多いにも かかわらず, Class 8 と Class 30 において分類精度の低下が見ら れた。原因として屋内散布と屋外散布とで付着量に大きな差が女 ることが挙げられる.これは, 農薬の付着量ごとに分類モデルを 構築することで改善される可能性がある.

屋内散布試料によって構築した分類モデルに屋外散布試料が適 用可能であったことから， SIMCA によって農薬の情報が抽出さ れ，同時に他の物質の影響を軽減できると考えられ，屋内試験の みでの実用的な分類モデル構築が期待される.

\section{表 8 屋内散布モデルにおける屋外散布試料の分類結果}

Table 8 Classification result of outside sample by interior model.

\begin{tabular}{lccccc}
\hline & Pred C0 & Pred C8 & Pred C30 & Pred C300 & Accuracy rate \\
\hline Class 0 & 10 & 0 & 0 & 0 & $100 \%$ \\
\hline Class 8 & 0 & 20 & 0 & 0 & $80 \%$ \\
\hline Class 30 & 0 & 2 & 20 & 0 & $80 \%$ \\
\hline Class 300 & 0 & 0 & 0 & 23 & $92 \%$ \\
\hline
\end{tabular}




\section{5. 結言}

本実験では，赤外分光法および SIMCA を併用することで，農薬 散布試料における濃度推定を試み, その妥当性について検討を行な った。 その結果, 屋内散布試験により調製したラブサイド®フロア ブル散布試料についてその付着濃度ごとのスペクトル分類が可能 であった．農薬付着の有無についても判別可能なことから，捕集材 としてポリエチレンが有効であることが確認された，そして，無人 ヘリコプター散布によって調製した実践的な試料についても付着 濃度ごとにスペクトル分類が可能であったことから, 赤外吸収特性 を利用した本手法の有用性を示すことができた．また，界面活性剤 などの成分に依存せず, 主に有効成分であるフサライドの情報によ って分類されていることから，フサライドを含有する他の農薬につ いても本手法を適用するその可能性を見出せたと言える．以上の結 果より, 赤外分光放射計測を利用することで, 迅速かつ簡便に農薬 の検出およびその付着濃度推定が可能であると考える. 本手法で は, 繁雑な前処理を要せず, 1 試料あたりの測定時間は約 1 分間で あった。

今後は, 更に低濃度の試料について分類を実施することで検出限 界について検証，ポジティブリスト制度への適用を図る．ただし， 当制度に適用する場合, 対象とする農作物の質量が大きく影響する ことから, 実際に農薬を散布した農作物と捕集材との付着量の対応 関係について検討する必要がある. 加えて, フサライドのみならず 他の農薬有効成分についても検討し, 本手法の汎用性を高めること も課題として挙げられる.

\section{謝辞}

本研究における農薬散布試験は, 社団法人農林水産航空協会農林 航空技術センター様の協力を得て実施したものである.ここに, 深 甚なる感謝の意を表する.

\section{参考文献}

（1）分野別施策 [食品中の残留農薬], www.mhlw.go.jp/topics/ bukyoku/iyaku/syoku-anzen/zanru2/index.html, 厚生労働省.

(2) 後藤真康, 加藤誠哉 編著 : 残留農薬分析法, ソフトサイエンス 社 (1980).

(3) M.Tsukioka, H.Ishizawa, T.Takano, H.Yamada, K.Nakagawa and N.Tanaka: Classification of Pesticide Residues in the Agricultural Products Based on Diffuse Reflectance IR Spectroscopy, SICE Annual Conference 2007, pp.216-219 (2007).

（4）高野友裕, 石澤広明, 本田和也, 山田久也, 田中信明 : 赤外放射 を用いた残留農薬検出と濃度分類, 第 41 回照学全大, pp.232-233 (2008).

（5）高野友裕, 石澤広明, 本田和也, 山田久也: 赤外分光スペクトル の特徵を用いた農薬のドリフト検出と濃度推定, 照学誌 , 93-5, pp.267-272 (2009).

（6）釘尾卓也，石澤広明，德竹翔太，本田和也：赤外分光情報による 非破壊農薬検出及び圃場散布管理, 計測自動制御学会中部支部 シンポジウム 2009 講演論文集, pp.45-46 (2009).

（7）吉成寬樹, 石澤広明, 堀口拓郎, 德竹翔太 : 赤外分光法に基づく 農薬の付着濃度検出, 計測自動制御学会中部支部シンポジウム
2010 講演論文集, pp.59-60 (2010).

（8）久野治義 : 赤外線工学, 電子情報通信学会, pp.1-13 (1994).

（9）増谷浩二：フーリエ変換赤外分光法, 学会出版センター, pp.88-96 (1991).

（10）相島鉄郎：ケモメトリックス, 丸善株式会社, pp.98102(1992).

（11）残留農薬, 飼料添加物, 動物用薬品の分析のご案内, www.jfrl.or.jp/item/pesticide/index.html，（財）日本食品 分析センター.

（受付日 2011 年 6 月 1 日/採録日 2012 年 1 月 5 日）

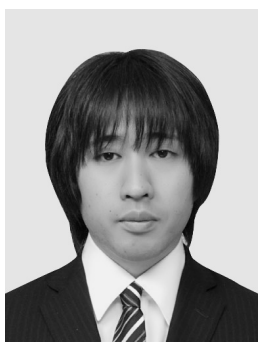

德竹 翔太 (正会員)

株式会社西澤電機計器製作所

干 389-0601 長野県埴科郡坂城町坂城 6249

2011 年 3 月に信州大学大学院工学系研究科 繊維システム工学専攻修了。同年 4 月, 株 式会社西澤電機計器製作所に入社，現在に 至る. ライフサポート学会会員.

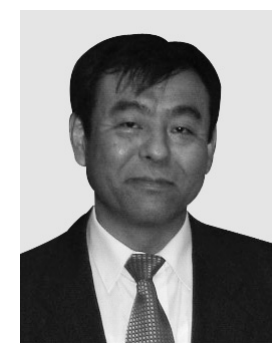

石澤 広明（正会員）

信州大学繊維学部創造工学系

干 386-8567 長野県上田市常田 3-15-1 1980 年東北大学大学院理学研究科物理学 専攻修士課程修了, (株)島津製作所, (社) 長野県農工研を経て 2002 年信州大学繊維 学部助教授, 2007 年同准教授, 現在に至 る. 博士 (工学). 分光放射の計測システ ムおよび産業応用に関する教育研究に従事. 照明学会/食物安全 への赤外放射応用研究調査委員会委員長 (2008 2009 年), 計測 自動制御学会, 日本文化財科学会, 感性工学会, 繊維学会などの 会員.

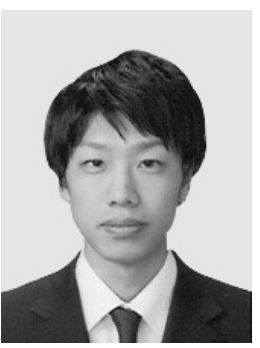

堀口拓郎（非会員）

信州大学大学院工学系研究科繊維システム 工学専攻

于386-8567 長野県上田市常田 3-15-1 2010 年 3 月に信州大学繊維学部繊維システ ム工学科卒業後, 同大学院へと進学, 現在 に至る. 計測自動制御学会会員.

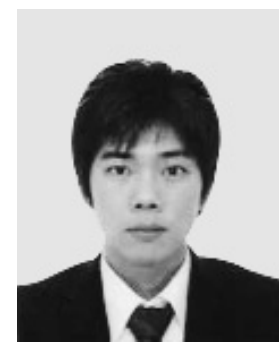

吉成 寛樹（非会員）

信州大学大学院工学系研究科繊維システム 工学専攻

于386-8567 長野県上田市常田 3-15-1 2011 年 3 月に信州大学繊維学部纎維システ ム工学科卒業後, 同大学院へと進学, 現在 に至る. 
山田 久也（正会員）

ヤンマーグリーンシステム株式会社＼cjkstart選果開 発グループ部長

干521-8521 滋賀県米原市梅ケ原 1600-4

1984 年京都大学大学院農学研究科修了後, 中

ンマーディーゼル(株)入社を経て現在に至る.

農業機械学会会員, 農学博士。 